\title{
ALLEVIATING THE ADVERSE EFFECTS OF SOIL SALINITY ON GROWTH AND PRODUCTIVITY OF "ROBY SEEDLESS" GRAPEVINES (Vitis vinifera L.) USING SOME SOIL AMENDMENTS
}

\author{
Manal G. Ibrahim and S. S. Bassiony \\ Viticulture Res. Dept. Horticulture Research Institute ARC, Giza, Egypt \\ Received: Jul. 22, 2019 \\ Accepted: Aug. 25, 2019
}

\begin{abstract}
Salinity is one of the most important factors facing the expansion of grapevine agricultural production which leads to reducing growth, yield and cluster quality. So, a field experiment was conducted during 2016 and 2017 seasons in a private vineyard situated in Desouk, Kafr El-Sheikh Governorate, Egypt, to evaluate effects of Humic acid at $15 \mathrm{~g}$ and $20 \mathrm{~g} / \mathrm{vine}$, potassium silicate at $20 \mathrm{~g}$ and $40 \mathrm{~g} / \mathrm{vine}$, and biofertilizer containing three bacterial strains (Azotobacter chroococcum+ Azospirllium lipoferm+ Bacillus megatherium with cell density $1 * 108 \mathrm{CFU} / \mathrm{g}$ ) at $50 \mathrm{~g} /$ vine alone or in combinations on growth, fruit quality and yield of "Ruby seedless" grapevines grown under soil salinity conditions. The results revealed that the combination treatments were more effective to alleviate the adverse effects of soil salinity than the individual ones. The combinations treatments among Humic acid, potassium silicate and biofertilizer at low (Humic acid at $\mathbf{1 5 g}+$ potassium silicate at $20 \mathrm{~g}+$ biofertilizer at $50 \mathrm{~g} / \mathrm{vine}$ ) and high (Humic acid at $30 \mathrm{~g}+$ potassium silicate at $40 \mathrm{~g}+$ biofertilizer at $50 \mathrm{~g} / \mathrm{vine}$ ) concentrations showed a superior effect on vegetative growth parameters such as leaf area, number of leaves per shoot, total chlorophyll, and vine vigor characters as lick cane length, coefficient of wood ripening, pruning's weight, internodes length, and diameter as compared with control. Moreover, caused a significant increase in leaf $N P K$ content, and reduced leaf proline content. Also, it enhanced berry physical parameters (berry diameter, weight and volume of 100 berries) and chemical parameters (SSC\%, SSC/acid ratio and anthocyanin content) as well as cluster number, length and weight consequently increased the total yield per feddan. Moreover, these applications reduced soil EC and $\mathrm{pH}$ meanwhile, enhanced both soils available NPK and microorganisms activity.
\end{abstract}

Key words: Humic acid, Potassium silicate, Biofertilizers, Ruby Seedless, Soil salinity

\section{INTRODUCTION}

Grapevine (Vitis vinifera L.) is an important horticultural crop. Soil salinity is a major problem faces the production; it reduces the physiological activities of plants; negatively affect plant growth and development (Cramer et al., 2007). Soil salinity developed as a result of some agricultural processes such as mineral fertilizers application excessively and irrigation with saline water (West, 1986). In Egypt, especially at the end of irrigation canals of the north delta as lick Desouk Kafr El-Sheikh Governorate, under these conditions farmers go to use drainage water for irrigation; this led to increasing the soil salinity. So, the salinity of soil is being a serious problem.

Grapevines classified as moderately sensitive to salt with differences among cultivars in this sensitivity (Obbink and Alexander, 1973). In this respect, Ayers and Westcot (1985) showed that, vines growing normally with $10 \%$ losing of production at EC 1.5-2.5 $\left(\mathrm{dSm}^{-1}\right)$ and when soil EC ranged from 2.5 to $4\left(\mathrm{dSm}^{-1}\right)$ the production get decreased by $10-15 \%$, whereas damage occurred at EC $4.7\left(\mathrm{dSm}^{-1}\right)$ with decrease 
in the productivity by $25-\mathbf{5 0} \%$. Generally, major effects of soil and water salinity is reducing the plant growth, dry matter accumulation, cluster number, berry size and total yield of grapevines (Walker et al., 2008). So, strategies for alleviating the negative effects of salinity on grapevine became very important for sustainable production and reduce the degradation of soil.

Grapes production could be enhanced by using some bio-stimulants such as humic acid which has effects on soil and plant growth through reducing salinity hazard on grapevine by reducing soil EC (Ali et al., 2013). Several studies have shown the beneficial effect of humic acid to mitigate salinity effects and enhancing plant growth, root initiation development, the mineral status of the plant, and the uptake of macro and micro nutrients (Buyukkeskin and Akinci, 2011; Celiket al., 2011 and Tahir et al., 2011). Also, it enhanced leaf chlorophyll contents and photosynthesis resulted in superior plant growth and increased cell membranes permeability that improved growth of the beneficial soil microorganisms. Moreover, it enhanced cell division and stimulates the growth of different fruit trees (Ferrara and Brunetti, 2010). In addition, the application of humic substances improved physical properties of soil and promotes the availability of many nutrients for plants (Cavalcante et al., 2013). In this respect, Tenshia and Singaram, (2005) reported that, humic acid application at $20 \mathrm{~kg} /$ ha improved the availability and uptake of both macro and micro nutrients.

Silicon ( $\mathrm{Si}$ ) is nonessential nutrient for plants, however it considered as a quasiessential nutrient. it has some beneficial effects as lick improving photosynthesis, vegetative growth, total yield and fruit quality of plants that grown under abiotic stresses as nutrient deficiency, drought, and salinity (Epstein and Bloom, 2005 and Bockhaven et al., 2013). Al-Wasfy (2014) reported that, Silicon applications as soil drench improved growth, yield and berries quality as well as enhanced both berry weight and cluster coloration of "Flame seedless" grapevines. Also, Si applications enhanced vegetative growth of "Cabernet Sauvignon" grapes grown under salt stress condition, enhanced the photosynthetic rates, and mitigated the inhibition of photosynthesis caused by $\mathrm{NaCl}$, moreover increased the total yield. Silicon might play an important role for protecting photosynthetic machinery and enhanced salt-tolerance of vines through increasing soluble sugars and starch concentration (Qin et al., 2016).

Bio-fertilizers are relatively one of the modern trends of agriculture production that aims to use the safest and least expensive natural materials. Bio-fertilizer products contain microorganisms that derived from plant roots or cultivated soil. These products have the potential to help plants grow under the unfavorable environment conditions like soil salinity and drought (Davies et al., 1991). In this respect, Anandaraj and Delapierre (2010) reported that, Bio-fertilizers are effective in improving plant drought tolerance, moisture stress and stimulate plant hormones production as a result of increase nitrogen fixation, phosphorous solubilization and nutrients uptake. Also, the application of Bio-fertilizers named Nitrobien, Phosphorien, and Halex increased vegetative growth, yield and leaf mineral content of "Flame seedless" grapevines Khalil (2012)

So, this study was conducted to investigate the potential effects of humic acid, silicon and biofertilizers on growth and productivity of "Ruby Seedless" grapevines grown under soil salinity conditions. 


\section{MATERIALS AND METHODS}

The present study was conducted during 2016 and 2017 seasons on "Ruby Seedless" grapevines grown in a private vineyard located at Desouk Kafr ELSheikh Governorate Egypt. Soil physical and chemical properties and irrigation water characters are shown in Tables (1 and 2). The vines had5years old, grown under flow irrigation system, spaced at $1.5^{\star} 3$ meters in a row and between rows, respectively, trained to bilateral cordons with modified $\mathrm{T}$ shape supporting system. Winter pruning was carried out during the last week of December leaving 20 fruiting spurs/ vine with 2 buds/ spur. The chosen vines were healthy and uniform in vigor with no visual defects. All tested vines received normal cultural practices usually used for grapevines in the study area. The vines were divided into eleven treatments including control, Humic acid (Black granules of potassium humate contains $75 \%$ Humic acid, $1 . \% \mathrm{~K}_{2} \mathrm{O}, 5 \%$ amino acids and $3 \%$ micro elements) at $15 \mathrm{~g}$ and $30 \mathrm{~g} /$ vine, Potassium silicate (commercial product contains $\mathrm{rv}, \diamond \% \mathrm{SiO}_{2}$ $+1 \mathrm{r} \% \mathrm{~K} 2 \mathrm{O}$ ) at $\mathbf{2 0 \mathrm { g }}$ and $40 \mathrm{~g} /$ vine. All treatments were applied alone and in combined with a biofertilizer product. This product was prepared by Soils, Water and Environment department, Sakha Agriculture Research Station, Kafr El-sheikh. This biofertilizer contains three bacterial strains named Azotobacter chroococcum, Azospirllium lipoferm and phosphate dissolving bacteria Bacillus megatherium with cell density 1 *108 CFU/ g) at $50 \mathrm{~g} / \mathrm{vine}$.

The treatments were:

$\mathrm{T}_{1}-$ Control,

$\mathrm{T}_{2}$ - Humic acid at $15 \mathrm{~g} / \mathrm{vine}$,

$\mathrm{T}_{3}$ - Humic acid at $30 \mathrm{~g} /$ vine,

$\mathrm{T}_{4}$ - Potassium silicate at $20 \mathrm{~g} /$ vine,

$\mathrm{T}_{5}$ - Potassium silicate at $40 \mathrm{~g} /$ vine,

T6- Humic acid at $15 \mathrm{~g} /$ vine+ Biofertilizer at $50 \mathrm{~g} /$ vine,

T7- Humic acid at $30 \mathrm{~g} /$ vine + Biofertilizer at $50 \mathrm{~g} /$ vine,

$\mathrm{T}_{8}$-Potassium silicate at $20 \mathrm{~g} /$ vine + Biofertilizer at $50 \mathrm{~g} /$ vine,

$\mathrm{T}_{9}$-Potassium silicate at $40 \mathrm{~g} /$ vine + Biofertilizer at $50 \mathrm{~g} /$ vine,

$\mathrm{T}_{10}$-Humic acid at $\mathbf{1 5 g}+$ Potassium silicate at $20 \mathrm{~g}+$ Biofertilizer at $50 \mathrm{~g} /$ vine (low level), and

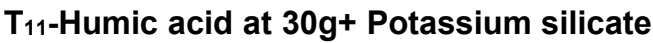

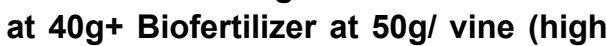
level).

All treatments were drenched with a service layer of soil with about $10 \mathrm{~cm}$ in depth of "Roby Seedless" grapevines root zoon area. These treatments were added two times in both seasons (once after winter pruning and one week after berry set). Each treatment contained three replicates with four vines/ replicate (12 vines/ treatment). This experiment was laid out as a randomized complete block designed.

Table 1: Physical and chemical characteristics of the experimental vineyard soil

\begin{tabular}{|c|c|c|c|c|c|c|c|c|c|c|c|c|c|c|}
\hline \multirow[b]{2}{*}{ Sand } & \multirow[b]{2}{*}{ Silt } & \multirow[b]{2}{*}{ Clay } & \multirow{2}{*}{$\begin{array}{l}\text { Soil } \\
\text { texture }\end{array}$} & \multirow{2}{*}{$\begin{array}{c}\text { Soil } \\
\text { Depth } \\
(\mathrm{cm})\end{array}$} & \multirow{2}{*}{$\begin{array}{c}E C \\
(d S / m)\end{array}$} & \multirow{2}{*}{$\begin{array}{c}\text { pH } \\
(1: 2.5)\end{array}$} & \multirow[b]{2}{*}{ SAR } & \multicolumn{4}{|c|}{ Cations ( meq/ L) } & \multicolumn{3}{|c|}{ Anions ( meq/ L) } \\
\hline & & & & & & & & $\mathrm{Ca}^{++}$ & $\mathbf{M g}^{++}$ & $+\mathrm{Na}^{++}$ & $\mathrm{K}^{+}$ & $\mathrm{HCO3}^{-}$ & $\mathrm{Cl}^{-}$ & SO4- \\
\hline 3.5 & 17.3 & 79.2 & 2 Clay & $0-60$ & 4.15 & 8.2 & 8.5 & 14.10 & 4.5 & 18.2 & 4.61 & 3.91 & 17.82 & 19.78 \\
\hline
\end{tabular}

Table 2: chemical analysis of irrigation water used in the experimental vineyard

\begin{tabular}{|c|c|c|c|c|c|c|c|c|c|}
\hline \multirow{2}{*}{$\begin{array}{c}\text { EC } \\
(\mathrm{dS} / \mathrm{m})\end{array}$} & \multirow{2}{*}{$\begin{array}{c}\mathrm{pH} \\
(1: 2.5)\end{array}$} & \multirow{2}{*}{ SAR } & \multicolumn{4}{|c|}{ Cations ( meq/L) } & \multicolumn{3}{|c|}{ Anions ( meq/L) } \\
\hline & & & $\mathrm{Ca}^{++}$ & $\mathbf{M g}^{++}$ & $\mathrm{Na}^{++}$ & $\mathrm{K}^{+}$ & $\mathrm{HCO}^{-}$ & $\mathrm{Cl}^{-}$ & SO4-- \\
\hline 0.71 & 7.63 & 3.02 & 2.18 & 0.89 & 3.75 & 0.32 & 1.85 & 2.65 & 2.64 \\
\hline
\end{tabular}


The following parameters were recorded:

1-Vegetative growth and vine vigor parameters:

1.1- Leaf area $\left(\mathrm{cm}^{2}\right)$ was measured using ten mature leaves per vine that collected from the opposite to basal clusters as recommended by Ahmed and Morsy (1999) with the help of the following equation:

Leaf area $\left(\mathrm{cm}^{2}\right)=0.56(0.79 *$ the maximum leaf width $\left.{ }^{2}\right)+20.01$

$1, Y$ - The number of leaves per shoot was counted on five shoots per vine at the end of growing seasons (when shoot apex becomes small, leaves of top shoots seem smaller in size with yellowish color and internodes being very short).

1,r-Leaf chlorophyll a, b and total chlorophyll $(a+b)$ contents were determined in mature leaves (leaves of $5-7^{\text {th }}$ position from the top of shoots) according to Wettstein (1957) and expressed as $\mathrm{mg} / 100 \mathrm{~g}$ of fresh weight.

1, \&-Cane length $(\mathrm{cm})$ was measured in six shoots/ vine at the end of both growing seasons (end of September).

1,0-Leaf proline content was estimated calorimetrically according to Bates et al. (1973)

1,7 -Leaf nutrient content was determinate in dry samples of mature leaves that collected from opposite to cluster. The determination of $\mathrm{N} \%$ was done using the modified micro-Kjeldahl apparatus according to Pregl (1945), $\mathrm{P} \%$ was determined coloremetrically according to Snell and Snell (1967) and $\mathrm{K} \%$ by using flame photometr method according to Jackson (1973).

$1, v$-Coefficient of wood ripening was measured at the end of the growing season in six canes per vine through dividing the ripened part length of cane (changing cane color from green to brownish) by total cane length according to Bouard (1966) as the following equation:

Coefficient of wood ripening $=$ $\frac{\text { length of ripened part of cane }}{\text { Total length of cane }}$

$1, \wedge$-Internodes length and diameter $(\mathrm{mm})$ were measured in the middle part of six canes/vine using vernier caliper at dormant period.

1,9-The total carbohydrate of cane was determined in the middle part of five canes per vine at the dormant time according to Hodge and Hofreiter (1962).

1, 1.-Weight of pruning's (kg) determined as weight of one-year-old wood per vine that removed during winter pruning

\section{2-Yield, clusters, and berries} quality parameters

At harvesting time (when SSC reached $16 \%$ ), cluster number/ vine were counted, cluster length $(\mathrm{cm})$ and average cluster weight were determined in ( $g$ ), and then total yield/feddan (ton) was calculated. Also, berries quality characters namely volume of 100 berries $(\mathrm{ml})$, weight of 100 berries $(\mathrm{g})$ and berry diameter $(\mathrm{mm})$ were determined. Also, SSC\% was measured with the help of hand refractometer according to Mazumdar and Majumder (2003). Berries juice acidity\% (mg tartaric acid/ $100 \mathrm{ml}$ juice) was determined according to A.O.A.C. (1995) and SSC/ acid ratio calculated. Berries anthocyanin content was determined calorimetrically according to Hsia et al. (1965) and expressed as $\mathrm{mg} / 100 \mathrm{~g}$ of fruits.

\section{3-Soil chemical characteristics}

Soil samples of vineyard were taken before applying the experiment and from root zone $(0-60 \mathrm{~cm}$ in depth) of each treatment at the end of the experiment. The samples were analyzed according to Jackson, (1973). These samples were 
dried, sieved through a $2 \mathrm{~mm}$ mesh and analysis for texture and, soil electrical conductivity (EC) which determined in 1: 5 soil-water extractions and soil reaction $(\mathrm{pH})$ values were estimated in 1:2.5 soils water suspensions. Soil soluble Cations $\left(\mathrm{Ca}^{++}, \mathrm{Mg}^{++}, \mathrm{Na}^{+}, \mathrm{K}^{+}\right)$and Anions $\left(\mathrm{CO}_{3}^{--}\right.$, $\mathrm{HCO}_{3}^{-}, \mathrm{Cl}^{-}$) were determined as meq/ $\mathrm{L}$ in the same extract and $\mathrm{SO}_{4}^{--}$was calculated. Soil $\mathbf{N}, \mathbf{P}$ and $\mathrm{K}$ were determined according to Page et al. (1982).

\section{4-Soil microbial activity}

The activity of soil microorganisms was measured as $\mathrm{CO}_{2}(\mathrm{mg} / \mathrm{kg}$ soil per day) produced. Fresh samples of soil were collected from vineyard before conduct the treatments and after both seasons of the study. The evaluation of $\mathrm{CO}_{2}$ was done according to Gaur et al., (1971). Samples of soil at $50 \mathrm{~g}$ were taken into $500 \mathrm{ml}$ conical flasks, and then a tube containing $10 \mathrm{ml}$ of $0.3 \mathrm{M} \mathrm{NaOH}$ solution was suspended in each flask, sealed with rubber bung and then incubated at $30^{\circ} \mathrm{C}$ for 20 days. The $\mathrm{CO}_{2}$ evolved and subsequently absorbed in $\mathrm{NaOH}$ was determined by using titration of $\mathrm{NaOH}$ solution against $0.1 \mathrm{M} \mathrm{HCl}$.

\section{5-Statistical analysis}

The obtained data were statistically analyzed as randomized complete block design by using analysis of variance according to Snedecor and Cochran (1980). The differences among treatment means were compared using Duncan's multiple range tests at $5 \%$ level according to Duncan (1955).

\section{RESULTS AND DISCUSSION}

\section{Vegetative growth parameters}

Data of Table (3) show the positive effects of Humic acid (potassium humate) and potassium silicate application alone as well as in combined with biofertilizer on growth parameters as lick leaf area cane length and the number of leaves/ shoot of "Ruby Seedless" grapevines. All treatments significantly enhanced these parameters as compared with control. The interaction among humic acid, Potassium silicate, and biofertilizer $\left(T_{7}, T_{8}, T_{9}, T_{10}\right.$ and $\left.T_{11}\right)$ treatments showed significantly the highest values of leaf area and cane length in both seasons, as well as number of leaves per shoot in the second one. On the other hand, control vines $\left(T_{1}\right)$ produced the lowest values of the abovementioned characters in both seasons. These results were supported by the data of correlation ( $r$ ) presented in Table (4) since, it could be noticed a highly positive correlation between both leaf area and cane length vs. pruning's weight $\left(0.76^{*}\right.$ and $\left.0.92^{* *}\right)$, cluster weight $\left(0.86^{*}\right.$ and $\left.0.75^{*}\right)$ however, they negatively correlated vs. leaf proline content $\left(-98^{* *}\right.$ and $\left.-0.85^{*}\right)$ and juice acidity $\left(-0.91^{*}\right.$ and $-0.82^{*}$, respectively).

These benefits of treatments may due to the effective role of Silicon element in protecting photosynthetic system and enhancing stress- tolerance throughout increasing soluble sugars and starch content which reflected on growth parameters (Qin et al., 2016). Also, these effects were cleared by the findings of Aziz et al. (2002) they reported that application of silicon to fruit trees grown under abiotic or biotic stress alleviated the adverse effects of the stress on growth and fruiting. This might don through maintaining plant water balance, photosynthesis rates, water transporting and organic. Also, potassium nutrient plays an important role regulation of the osmotic potential that an important plant mechanism for water relations controls maintenance cell turgor and plant growth as showed as early by Davies and Zhang (1991). 
Table r: Effect of Humic acid, Potassium Silicate and Biofertilizer on leaf area and number of leaves per shoot of "Ruby Seedless" grapevines during 2016 and 2017 seasons.

\begin{tabular}{c|llllll}
\hline \multirow{2}{*}{ Treatments } & \multicolumn{2}{|c}{$\begin{array}{c}\text { Leaf area } \\
\left(\mathrm{cm}^{2}\right)\end{array}$} & \multicolumn{2}{c}{$\begin{array}{c}\text { Cane length } \\
(\mathrm{cm})\end{array}$} & \multicolumn{2}{c}{$\begin{array}{c}\text { Number of leaves } \\
\text { per shoot }\end{array}$} \\
\cline { 2 - 7 } & 2016 & 2017 & 2016 & 2017 & 2016 & 2017 \\
\hline $\mathrm{T}_{1}$ & $96.58^{\mathrm{f}}$ & $91.46^{\mathrm{e}}$ & $110.37 \mathrm{f}$ & $122.72^{\mathrm{e}}$ & $17 . r$ re & $19.67^{\mathrm{e}}$ \\
$\mathrm{T}_{2}$ & $102.23^{\mathrm{e}}$ & $98.35^{\mathrm{d}}$ & $118.25^{\mathrm{e}}$ & $131.56^{\mathrm{d}}$ & $20.52^{\text {de }}$ & $23.52^{\mathrm{de}}$ \\
$\mathrm{T}_{3}$ & $112.42^{\mathrm{d}}$ & $105.75^{\mathrm{c}}$ & $126.43^{\mathrm{d}}$ & $140.56^{\mathrm{c}}$ & $21.33^{\mathrm{de}}$ & $25.33^{\mathrm{cd}}$ \\
$\mathrm{T}_{4}$ & $115.37^{\mathrm{d}}$ & $108.58^{\mathrm{c}}$ & $133.52^{\mathrm{c}}$ & $148.45^{\mathrm{b}}$ & $23.67^{\mathrm{cd}}$ & $26.33^{\mathrm{bcd}}$ \\
$\mathrm{T}_{5}$ & $121.63^{\mathrm{c}}$ & $114.37^{\mathrm{b}}$ & $143.65^{\mathrm{b}}$ & $152.35^{\mathrm{b}}$ & $23.33^{\mathrm{cd}}$ & $29.52^{\mathrm{abc}}$ \\
$\mathrm{T}_{6}$ & $125.71^{\mathrm{b}}$ & $116.42^{\mathrm{b}}$ & $141.62^{\mathrm{b}}$ & $150.52^{\mathrm{b}}$ & $26.33^{\mathrm{bc}}$ & $28.33^{\mathrm{abc}}$ \\
$\mathrm{T}_{7}$ & $133.28^{\mathrm{a}}$ & $122.43^{\mathrm{a}}$ & $155.38^{\mathrm{a}}$ & $165.26^{\mathrm{a}}$ & $28.52^{\mathrm{ab}}$ & $30.52^{\mathrm{a}}$ \\
$\mathrm{T}_{8}$ & $135.24^{\mathrm{a}}$ & $124.37^{\mathrm{a}}$ & $154.53^{\mathrm{a}}$ & $163.34^{\mathrm{a}}$ & $30.52^{\mathrm{ab}}$ & $32.33^{\mathrm{a}}$ \\
$\mathrm{T}_{9}$ & $136.53^{\mathrm{a}}$ & $125.71^{\mathrm{a}}$ & $156.41^{\mathrm{a}}$ & $166.24^{\mathrm{a}}$ & $31.67^{\mathrm{a}}$ & $31.80^{\mathrm{a}}$ \\
$\mathrm{T}_{10}$ & $136.71^{\mathrm{a}}$ & $126.62^{\mathrm{a}}$ & $155.61^{\mathrm{a}}$ & $164.38^{\mathrm{a}}$ & $32.33^{\mathrm{a}}$ & $32.33^{\mathrm{a}}$ \\
$\mathrm{T}_{11}$ & $136.63^{\mathrm{a}}$ & $128.42^{\mathrm{a}}$ & $156.24^{\mathrm{a}}$ & $162.43^{\mathrm{a}}$ & $31.80^{\mathrm{a}}$ & $32.52^{\mathrm{a}}$ \\
\hline
\end{tabular}

In a column, numbers followed by the same litter had no significant difference at $5 \%$ level by DMRT.

$T_{1}=$ Control, $T_{2}=$ Humic acid at 15g/vine, $T_{3}=$ Humic acid at $30 \mathrm{~g} / \mathrm{vine}, T_{4}=$ Potassium silicate at $20 \mathrm{~g} / \mathrm{vine}$, $T_{5}=$ Potassium silicate at $40 \mathrm{~g} / \mathrm{vine}, T_{6}=$ Humic acid at $15 \mathrm{~g}+$ Biofertilizer at $50 \mathrm{~g} / \mathrm{vine}, T_{7}=$ Humic acid at $30 \mathrm{~g}+$ Biofertilizer at $50 \mathrm{~g} / \mathrm{vine}, T_{8}=$ Potassium silicate at $20 \mathrm{~g}+$ Biofertilizer at $50 \mathrm{~g} / \mathrm{vine}, \mathrm{T}_{9}=$ Potassium silicate at $40 \mathrm{~g}+$ Biofertilizer at $50 \mathrm{~g} / \mathrm{vine}, T_{10}=$ Humic acid at $15 \mathrm{~g}+$ Potassium silicate at $20 \mathrm{~g}+$ Biofertilizer at $50 \mathrm{~g} / \mathrm{vine}$ and $T_{11}=$ Humic acid at $30 \mathrm{~g}+$ Potassium silicate at $40 \mathrm{~g}+$ Biofertilizer at $50 \mathrm{~g} / \mathrm{vine}$.

Table 4: The Pearson Correlation Coefficient ( $r$ ) among some chosen parameters of "Ruby Seedless" grapevine as affected by the addition of Humic acid, Potassium silicate and biofertilizer

\begin{tabular}{|c|c|c|c|c|c|c|c|c|c|c|c|}
\hline Characters & 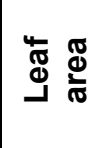 & 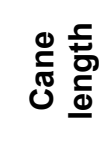 & 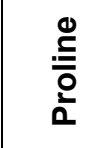 & 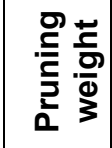 & 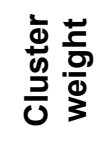 & 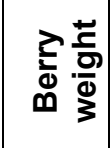 & $\frac{\overline{0}}{\frac{\pi}{0}}$ & \& & $\frac{7}{\frac{7}{0}}$ & \begin{tabular}{|l|}
$\bar{J}$ \\
$\frac{\pi}{0}$ \\
$\mathscr{S}$ \\
$\mathscr{S}$
\end{tabular} & 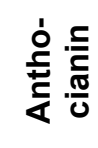 \\
\hline Leaf area & 1.00 & & & & & & & & & & \\
\hline Cane length & $0.83^{*}$ & 1.00 & & & & & & & & & \\
\hline Proline & $-0.98^{* *}$ & $-0.85^{*}$ & 1.00 & & & & & & & & \\
\hline Pruning $\mathbf{W}$. & $0.76^{*}$ & $0.92^{* *}$ & $-0.90^{*}$ & 1.00 & & & & & & & \\
\hline Cluster W. & $0.86^{*}$ & $0.75^{*}$ & $-0.92^{*}$ & $0.86^{*}$ & 1.00 & & & & & & \\
\hline Berry weight & $0.89^{*}$ & $0.72^{*}$ & $-0.91^{*}$ & $0.87^{\star}$ & $0.88^{*}$ & 1.00 & & & & & \\
\hline Yield/feddan & $0.85^{\star}$ & $0.76^{*}$ & $-0.88^{*}$ & $0.82^{*}$ & $0.92^{* *}$ & $0.89^{*}$ & 1.00 & & & & \\
\hline ssc & $0.79^{*}$ & $0.81^{*}$ & $-0.90^{*}$ & $0.88^{*}$ & $0.87^{\star}$ & $0.89^{*}$ & $0.88^{*}$ & 1.00 & & & \\
\hline Acidity & $-0.91^{*}$ & $-0.82^{*}$ & $0.78^{*}$ & $-0.95^{* *}$ & $-0.73^{*}$ & $-0.87^{*}$ & $-0.73^{*}$ & $-0.85^{*}$ & 1.00 & & \\
\hline SSC/acid & $0.80^{*}$ & $0.75^{*}$ & $-0.72^{*}$ & $0.89^{*}$ & $0.81^{*}$ & $0.83^{*}$ & $0.77^{*}$ & $0.82^{*}$ & $-0.99^{* \star}$ & 1.00 & \\
\hline Anthocyanin & $0.89^{*}$ & $0.88^{*}$ & $-0.91^{*}$ & $0.89^{*}$ & $0.87^{*}$ & $0.89^{*}$ & $0.90^{*}$ & $0.89^{*}$ & $-0.90^{*}$ & $0.94^{*}$ & 1.00 \\
\hline
\end{tabular}

${ }^{*}$ and ${ }^{* *}=$ significance at 0.05 and 0.01 , respectively. 


\section{Leaf chlorophyll content}

Data illustrated as Figures $\left(1_{A}\right),\left(1_{B}\right)$ and (1c) show that, leaf chlorophyll a, b and total chlorophyll contents were positively affected as a result of all treatments. The combined applications were more effective than individual ones. The grapevines received $T_{9}, T_{10}$ and $T_{11}$ treatments showed the highest values of chlorophyll a and total chlorophyll content, however the highest values of chlorophyll $b$ was noticed with vines that treated by $T_{8}, T_{9}, T_{10}$ and $\mathrm{T}_{11}$. On the other hand, the lowest values of chlorophyll a were showed in vines treated by $T_{2}$ and control $\left(T_{1}\right)$. This trend was true in both seasons of the study. These results are in harmony with those of Ferrara et al. (2012) and Haynes (2014) who concluded that applications of Humic acid enhanced shoot growth, increased leaf chlorophyll contents and higher SPAD values of "Italia" table grape. Also, Liang et al. (2007) cleared that, the addition of silicon improved all growth parameters and photosynthetic rates of plants grown under salt stress.
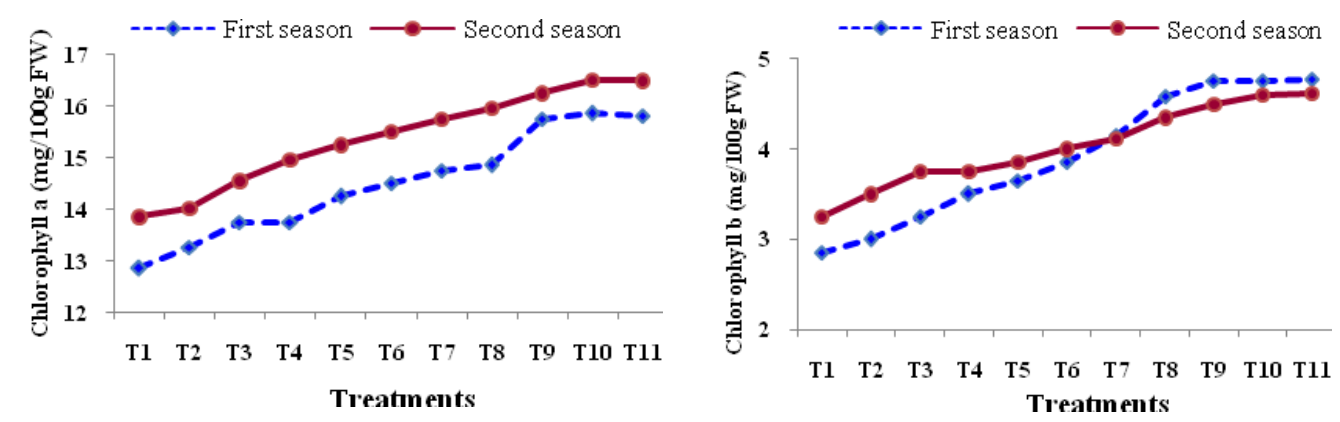

Chlorophyll a (A)

Chlorophyll b (B)

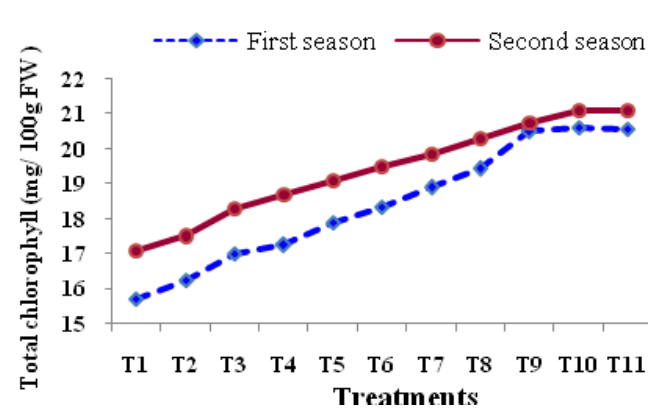

Total chlorophyll (C)

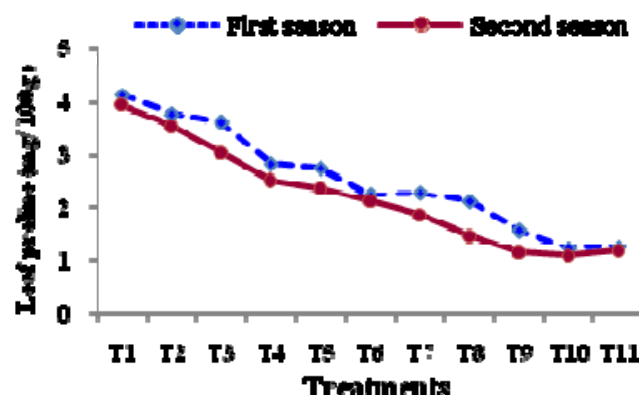

Proline content (D)

Figure 1. Effect of Humic acid, Potassium silicate and biofertilizer on leaf chlorophyll a (A), chlorophyll b (B) total chlorophyll (C) and leaf proline content (D) of "Ruby Seedless" grapevines during 2016 and 2017 seasons

$T_{1}=$ Control, $T_{2}=$ Humic acid at 15g/vine, $T_{3}=$ Humic acid at $30 \mathrm{~g} / \mathrm{vine}, T_{4}=$ Potassium silicate at $20 \mathrm{~g} / \mathrm{vine}$, $T_{5}=$ Potassium silicate at $40 \mathrm{~g} / \mathrm{vine}, T_{6}=$ Humic acid at $15 \mathrm{~g}+$ Biofertilizer at $50 \mathrm{~g} / \mathrm{vine}, T_{7}=$ Humic acid at $30 \mathrm{~g}+$ Biofertilizer at $50 \mathrm{~g} / \mathrm{vine}, T_{8}=$ Potassium silicate at $20 \mathrm{~g}+$ Biofertilizer at $50 \mathrm{~g} / \mathrm{vine}, \mathrm{T}_{9}=$ Potassium silicate at $40 \mathrm{~g}+$ Biofertilizer at $50 \mathrm{~g} / \mathrm{vine}, \mathrm{T}_{10}=$ Humic acid at $15 \mathrm{~g}+$ Potassium silicate at $20 \mathrm{~g}+$ Biofertilizer at 50g/vine and $T_{11}=$ Humic acid at $30 \mathrm{~g}+$ Potassium silicate at $40 \mathrm{~g}+$ Biofertilizer at $50 \mathrm{~g} / \mathrm{vine}$. 


\section{Leaf proline content}

Data established as Figure (1D) display

the beneficial effects of Humic acid, potassium silicate and biofertilizer on reducing leaf proline content which indicates to reducing the adverse effects of soil salinity on vine growth, this positive effect was in ascending degree with the concentrations of treatments. Potassium silicate at high level plus biofertilizer $\left(T_{9}\right)$, the interaction among the three substances at low $\left(\mathrm{T}_{10}\right)$ and high levels $\left(T_{11}\right)$ treatments, showed the lowest values of leaf proline contents $(1.55,1.21$ and $1.24 \mathrm{mg} / 100 \mathrm{~g}$, respectively) in the first season and $(1.13,1.07$ and $1.15 \mathrm{mg} / 100$, respectively) in the second one. On the other hand, vines of control $\left(\mathrm{T}_{1}\right)$ showed the highest values (4.12 and 3.92 , respectively) during both seasons.

These results were supported by data of correlation ( $r$ ) presented in Table (4) where, leaf proline content showed a negative correlation vs. pruning's weight $\left(-90^{*}\right)$, leaf area $\left(-0.98^{* *}\right)$, cluster weight ($\left.0.92^{*}\right)$ and berry chemical parameters (SSC\%, SSC/acid ratio and anthocyanin content) however, it positively correlated vs. juice acidity $\left(0.78^{*}\right)$.The reduction of leaf proline content probably might due to important role of silicon in enhancing the salt tolerance by increasing soluble sugars and starch concentrations (Qin et al., 2016). The maximum concentration of proline recorded with vines of control could be explained as early as showed by Salisbury and Ross (1992) they reported that rising of proline in leaves of some plants might be due to rising the hydrolytic enzymes that caused by soil salinity. Moreover, Murkute et al. (2005) reported that some plant species accumulate proline (20-100 $\mu \mathrm{mol} \mathrm{g} \mathrm{g}^{-1}$ dry mass) under salt stress. Proline levels showed a linear relation with high $\mathrm{NaCl}$ concentrations.

\section{Leaf nutrients content}

Leaf $\mathrm{N}, \mathrm{P}$ and $\mathrm{K}$ contents of "Ruby Seedless" grapevines were enhanced as a result of applications of humic acid, potassium silicate and biofertilizer (Table 5). The interaction applications of $T_{7}, T_{8}$, $T_{9}, T_{10}$ and $T_{11}$ recorded the highest values of leaf $\mathbf{N}$ content; however applications of $T_{8}, T_{9}, T_{10}$ and $T_{11}$ resulted in the highest values of leaf $P$ and $K$ contents. In contrast, vines of control $\left(T_{1}\right)$ and that received $T_{2}$ showed the lowest values of the three nutrients (NPK) in most cases. This trend was true during both seasons. The positive action of these treatments on vine nutritional status mainly due to the role of these substances in reducing soil salinity, soil $\mathrm{pH}$, leaching process and enhancing the development of roots, nutrient availability, production of natural hormones, microbial activity and soil nutrients (Davis and Ghabbour, 1998 and El-Rawy, 2007). These results are in harmony with the findings of Solimanet al. (2013) they reported that application of potassium humate at $20 \mathrm{~kg} /$ ha enhanced the availability and uptake of micro and macro nutrients, however decreased leaf$\mathrm{Na}$. Also, potassium humate applications enhanced $\mathrm{N}, \mathrm{P}, \mathrm{K}, \mathrm{Fe}, \mathrm{Mg}$ contents of "Thompson Seedless" leaves (Ali et al., 2013). In addition, the application of potassium silicate improved nutrients supply, vegetative growth of grapevines and resistance to mitigate the biotic and abiotic stresses (Meunier et al., 2011). 
Table 5 :Effect of Humic acid, Potassium silicate and biofertilizer on leaf N.P.K content of "Ruby Seedless" grapevines during 2016 and 2017 seasons

\begin{tabular}{c|llllll}
\hline \multirow{2}{*}{ Treatments } & \multicolumn{3}{|c}{$\mathrm{N} \%$} & \multicolumn{2}{c}{$\mathrm{P} \%$} & \multicolumn{2}{c}{$\mathrm{K} \%$} \\
\cline { 2 - 7 } & 2016 & 2017 & 2016 & 2017 & 2016 & 2017 \\
\hline $\mathrm{T}_{1}$ & $1.23^{\mathrm{d}}$ & $1.33^{\mathrm{c}}$ & $0.31^{\mathrm{d}}$ & $0.25^{\mathrm{f}}$ & $1.22^{\mathrm{e}}$ & $1.31^{\mathrm{e}}$ \\
$\mathrm{T}_{2}$ & $1.35^{\mathrm{cd}}$ & $1.45^{\mathrm{c}}$ & $0.33^{\mathrm{d}}$ & $0.26^{\mathrm{f}}$ & $1.24^{\mathrm{e}}$ & $1.34^{\mathrm{de}}$ \\
$\mathrm{T}_{3}$ & $1.47^{\mathrm{bcd}}$ & $1.52^{\mathrm{bc}}$ & $0.37^{\mathrm{cd}}$ & $0.32^{\mathrm{de}}$ & $1.31^{\mathrm{d}}$ & $1.38^{\mathrm{cde}}$ \\
$\mathrm{T}_{4}$ & $1.52^{\mathrm{bc}}$ & $1.54^{\mathrm{bc}}$ & $0.42^{\mathrm{c}}$ & $0.37^{\mathrm{cd}}$ & $1.36^{\mathrm{cd}}$ & $1.40^{\mathrm{bcd}}$ \\
$\mathrm{T}_{5}$ & $1.63^{\mathrm{ab}}$ & $1.72^{\mathrm{ab}}$ & $0.48^{\mathrm{b}}$ & $0.38^{\mathrm{cd}}$ & $1.41^{\mathrm{c}}$ & $1.44^{\mathrm{bc}}$ \\
$\mathrm{T}_{6}$ & $1.65^{\mathrm{ab}}$ & $1.71^{\mathrm{ab}}$ & $0.50^{\mathrm{b}}$ & $0.41^{\mathrm{bc}}$ & $1.47^{\mathrm{b}}$ & $1.41^{\mathrm{bcd}}$ \\
$\mathrm{T}_{7}$ & $1.82^{\mathrm{a}}$ & $1.80^{\mathrm{a}}$ & $0.53^{\mathrm{b}}$ & $0.45^{\mathrm{b}}$ & $1.50^{\mathrm{b}}$ & $1.47^{\mathrm{b}}$ \\
$\mathrm{T}_{8}$ & $1.87^{\mathrm{a}}$ & $1.79^{\mathrm{a}}$ & $0.65^{\mathrm{a}}$ & $0.55^{\mathrm{a}}$ & $1.65^{\mathrm{a}}$ & $1.61^{\mathrm{a}}$ \\
$\mathrm{T}_{9}$ & $1.82^{\mathrm{a}}$ & $1.85^{\mathrm{a}}$ & $0.68^{\mathrm{a}}$ & $0.53^{\mathrm{a}}$ & $1.69^{\mathrm{a}}$ & $1.63^{\mathrm{a}}$ \\
$\mathrm{T}_{10}$ & $1.88^{\mathrm{a}}$ & $1.91^{\mathrm{a}}$ & $0.68^{\mathrm{a}}$ & $0.56^{\mathrm{a}}$ & $1.68^{\mathrm{a}}$ & $1.62^{\mathrm{a}}$ \\
$\mathrm{T}_{11}$ & $1.81^{\mathrm{a}}$ & $1.90^{\mathrm{a}}$ & $0.67^{\mathrm{a}}$ & $0.55^{\mathrm{a}}$ & $1.67^{\mathrm{a}}$ & $1.64^{\mathrm{a}}$ \\
\hline
\end{tabular}

In a column, numbers followed by the same litter had no significant difference at $5 \%$ level by DMRT.

$T_{1}=$ Control, $T_{2}=$ Humic acid at $15 \mathrm{~g} / \mathrm{vine}, T_{3}=$ Humic acid at $30 \mathrm{~g} / \mathrm{vine}, T_{4}=$ Potassium silicate at $20 \mathrm{~g} / \mathrm{vine}$, $T_{5}=$ Potassium silicate at $40 \mathrm{~g} / \mathrm{vine}, T_{6}=$ Humic acid at $15 \mathrm{~g}+$ Biofertilizer at $50 \mathrm{~g} / \mathrm{vine}, T_{7}=$ Humic acid at $30 \mathrm{~g}+$ Biofertilizer at $50 \mathrm{~g} / \mathrm{vine}, T_{8}=$ Potassium silicate at $20 \mathrm{~g}+$ Biofertilizer at $50 \mathrm{~g} / \mathrm{vine}, T_{9}=$ Potassium silicate at $40 \mathrm{~g}+$ Biofertilizer at $50 \mathrm{~g} / \mathrm{vine}, \mathrm{T}_{10}=$ Humic acid at $15 \mathrm{~g}+$ Potassium silicate at $20 \mathrm{~g}+$ Biofertilizer at $50 \mathrm{~g} / \mathrm{vine}$ and $T_{11}=$ Humic acid at $30 \mathrm{~g}+$ Potassium silicate at $40 \mathrm{~g}+$ Biofertilizer at $50 \mathrm{~g} / \mathrm{vine}$.

\section{Vine vigor parameters}

Data in Table (6) indicate the enhancement effect of humic acid, potassium silicate either alone or in combined with biofertilizer on vine vigor parameters in terms of coefficient of wood ripening, internodes diameter and length of "Ruby Seedless" grapevines. All treatments significantly enhanced these parameters compared to control $\left(T_{1}\right)$. The vines that supplied with $T_{9}, T_{10}$ and $T_{11}$ treatments resulted in the highest values of coefficient of wood ripening and internodes diameter as well as total carbohydrates per cane. Meanwhile, the application of $T_{8}, T_{9}, T_{10}$ and $T_{11}$ produced the highest values of the internodes length without significant differences among them. Also, the addition of both low and high levels of Humic acid, potassium silicate and biofertilizer $\left(T_{10}\right.$ and $T_{11}$ ) treatments, showed significantly the highest values of pruning weight per vine. On the contrary, vines of control $\left(T_{1}\right)$ showed the lowest values of the abovementioned characters in most cases. These results had been confirmed during both seasons and supported by the correlation ( $r$ ) data presented in Table (4) since, pruning's weight showed a positive correlation vs. leaf area $\left(0.76^{*}\right)$, cluster weight $\left(0.86^{*}\right)$, and yield/ feddan $\left(0.82^{*}\right)$. However, it negatively correlated vs. leaf proline content $\left(-0.90^{*}\right)$. The encourage effect of these applications might due to the addition of siliceous substances helps plant for mitigate the inhibition effect caused by soil salinity on photosynthesis activity which increase the potential photochemical production as well as increased the availability of nutrients, reduced soil $\mathrm{pH}$ and salinity, 
improved soil exchange capacity and controlling stomata behavior as well as improved nutrients uptake (Qin et al., 2016). These results are in agreement with the findings of Tuna et al. (2008) they reported that, the exogenous supply of silicon compounds could be used as an alternative strategy to mitigating the negative effects of salts on plant growth and yield. Also, Gabr and Nour El-Din (2012) and Mansour et al. (2013) focused that, the application of nitrogen-fixing bacteria (Azospirillum lipoferum) enhanced the nitrogen status of peach orchards and produce natural hormones like gibberellins and cytokines that are responsible for plant growth promotion.

\section{Yield and cluster characters}

Data showed in Figures $\left(2_{A-D}\right)$ pointed out that yield components (cluster number, length and weight) and yield per feddan improved as a result of the addition of Humic acid, potassium silicate and biofertilizer. The interaction among these substances regardless concentration plus biofertilizer ( $T_{10}$ and $\left.T_{11}\right)$ treatments produced the highest cluster weight as compared with other treatments and control $\left(T_{1}\right)$ in both seasons. The addition of $T_{8}, T_{9}, T_{10}$ and $\mathrm{T}_{11}$ treatments produced the longest cluster length as compared to other treatments in both seasons. The vines that received $T_{8} T_{10}$ and $T_{11}$ treatments showed the highest number of clusters in the first season however, in the second one, application of $T_{9}, T_{10}$, and $T_{11}$ produced the highest number of clusters. The highest total yield per feddan was recorded with the using of $T_{10}$ and $T_{11}$ applications in the first season and $T_{9}, T_{10}$ and $T_{11}$ in the second one.

Table 6: Effect of Humic acid, Potassium silicate and biofertilizer on vine vigor parameters of "Ruby Seedless" grapevines during 2016 and 2017 seasons

\begin{tabular}{|c|c|c|c|c|c|c|c|c|c|c|}
\hline \multirow[t]{2}{*}{ Treatments } & \multicolumn{2}{|c|}{$\begin{array}{l}\text { Coefficient } \\
\text { of wood } \\
\text { ripening }\end{array}$} & \multicolumn{2}{|c|}{$\begin{array}{l}\text { Internodes } \\
\text { diameter } \\
\text { (cm) }\end{array}$} & \multicolumn{2}{|c|}{$\begin{array}{l}\text { Internodes } \\
\text { length } \\
\text { (cm) }\end{array}$} & \multicolumn{2}{|c|}{$\begin{array}{c}\text { Total } \\
\text { carbohydrates } \\
\text { of cane } \\
(\mathrm{mg} / 100 \mathrm{~g})\end{array}$} & \multicolumn{2}{|c|}{$\begin{array}{l}\text { Pruning } \\
\text { weight } \\
\text { (Kg) }\end{array}$} \\
\hline & 2016 & 2017 & 016 & 2017 & 2016 & 2017 & 2016 & 2017 & 2016 & 2017 \\
\hline$T_{1}$ & $0.48^{d}$ & $0.52^{c}$ & $.83^{c}$ & $1.71^{\mathrm{e}}$ & $5.71^{\mathrm{e}}$ & 5.5 & $9.70^{\mathrm{g}}$ & $10.10^{f}$ & $1.85^{\mathrm{g}}$ & $1.94^{f}$ \\
\hline $\mathbf{T}_{2}$ & $0.52^{d}$ & r 5 b & $1.98^{\mathrm{bc}}$ & $1.87^{\mathrm{de}}$ & $5.93^{e}$ & $5.65^{c}$ & $10.20^{f}$ & $10.80^{\mathrm{e}}$ & $2.00^{\mathrm{fg}}$ & $2.12^{\mathrm{e}}$ \\
\hline $\mathbf{T}_{3}$ & $0.58^{\mathrm{cd}}$ & $0.61^{b c}$ & $2.04^{b c}$ & & $6.34^{d}$ & $6.02^{b}$ & $10.53^{f}$ & $11.30^{\mathrm{d}}$ & $2.15^{\mathrm{ef}}$ & $18^{e}$ \\
\hline $\mathrm{T}_{4}$ & $0.64^{\text {bcd }}$ & $0.65^{b c}$ & $2.12^{\mathrm{abc}}$ & $=2.02^{b-e}$ & $6.75^{c}$ & $6.43^{b}$ & $10.92^{e}$ & $11.67^{\mathrm{cd}}$ & $2.23^{\mathrm{de}}$ & $2.31^{d}$ \\
\hline$T_{5}$ & $0.68^{a b c}$ & $0.65^{b c}$ & $2.20^{\mathrm{abc}}$ & $=2.12^{\mathrm{bcd}}$ & $6.76^{c}$ & $6.92^{\mathrm{ab}}$ & $11.42^{\mathrm{d}}$ & $11.88^{\mathrm{c}}$ & $2.27^{\text {cde }}$ & $2.34^{d}$ \\
\hline $\mathrm{T}_{6}$ & $0.69^{a b c}$ & 0.7 & $2.28^{\mathrm{ab}}$ & $2.22^{\mathrm{abc}}$ & $6.98^{b c}$ & $7.15^{\mathrm{ab}}$ & $11.85^{c}$ & $12.33^{b}$ & $2.33^{\text {cde }}$ & $2.41^{\mathrm{cd}}$ \\
\hline $\mathbf{T}_{7}$ & $0.73^{\mathrm{ab}}$ & $0.73^{\mathrm{ab}}$ & $2.32^{\mathrm{ab}}$ & $2.28^{\mathrm{abc}}$ & $7.24^{b}$ & $7.13^{a b}$ & $12.33^{b}$ & $12.51^{b}$ & $2.42^{\mathrm{cd}}$ & $2.48^{b c}$ \\
\hline $\mathrm{T}_{8}$ & $0.74^{\mathrm{ab}}$ & $0.73^{a b}$ & $2.35^{\mathrm{ab}}$ & $2.31^{\mathrm{ab}}$ & $7.93^{a}$ & $7.87^{a}$ & $12.52^{b}$ & $12.53^{b}$ & $2.46^{\mathrm{bc}}$ & $2.51^{b c}$ \\
\hline $\mathrm{T}_{9}$ & $0.75^{a}$ & $0.76^{a}$ & $2.41^{a}$ & $2.52^{\mathrm{a}}$ & $7.94^{\mathrm{a}}$ & $7.82^{\mathrm{a}}$ & $12.95^{\mathrm{a}}$ & $13.18^{\mathrm{a}}$ & $2.64^{\mathrm{ab}}$ & $2.58^{\mathrm{b}}$ \\
\hline$T_{10}$ & $0.76^{a}$ & $0.77^{a}$ & $2.45^{a}$ & $2.54^{a}$ & $8.14^{a}$ & $7.89^{a}$ & $13.15^{a}$ & $13.25^{\mathrm{a}}$ & $2.78^{a}$ & $2.70^{\mathrm{a}}$ \\
\hline $\mathbf{T}_{11}$ & $0.75^{a}$ & $0.76^{a}$ & $2.42^{\mathrm{a}}$ & $2.58^{a}$ & $8.11^{a}$ & $8.18^{a}$ & $13.21^{a}$ & $13.21^{\mathrm{a}}$ & $2.82^{\mathrm{a}}$ & $2.79^{a}$ \\
\hline
\end{tabular}

In a column, numbers followed by the same litter had no significant difference at $5 \%$ level by DMRT.

$T_{1}=$ Control, $T_{2}=$ Humic acid at 15g/vine, $T_{3}=$ Humic acid at 30g/vine, $T_{4}=$ Potassium silicate at $20 \mathrm{~g} / \mathrm{vine}$, $T_{5}=$ Potassium silicate at $40 \mathrm{~g} / \mathrm{vine}, T_{6}=$ Humic acid at $15 \mathrm{~g}+$ Biofertilizer at $50 \mathrm{~g} / \mathrm{vine}, T_{7}=$ Humic acid at $30 \mathrm{~g}+$ Biofertilizer at $50 \mathrm{~g} / \mathrm{vine}, T_{8}=$ Potassium silicate at $20 \mathrm{~g}+$ Biofertilizer at $50 \mathrm{~g} / \mathrm{vine}, T_{9}=$ Potassium silicate at $40 \mathrm{~g}+$ Biofertilizer at 50g/vine, $T_{10}=$ Humic acid at $15 \mathrm{~g}+$ Potassium silicate at $20 \mathrm{~g}+$ Biofertilizer at 50g/vine and $T_{11}=$ Humic acid at $30 \mathrm{~g}+$ Potassium silicate at $40 \mathrm{~g}+$ Biofertilizer at $50 \mathrm{~g} / \mathrm{vine}$. 


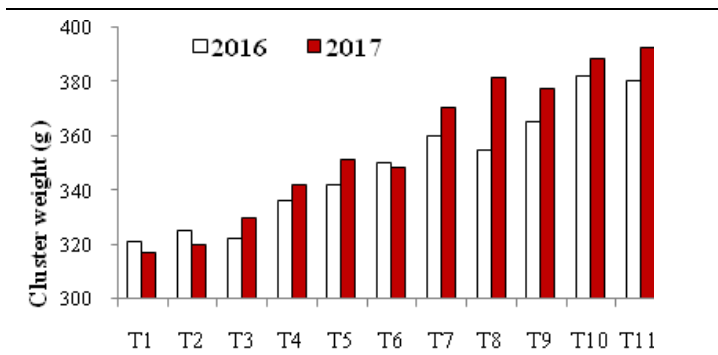

Treatments

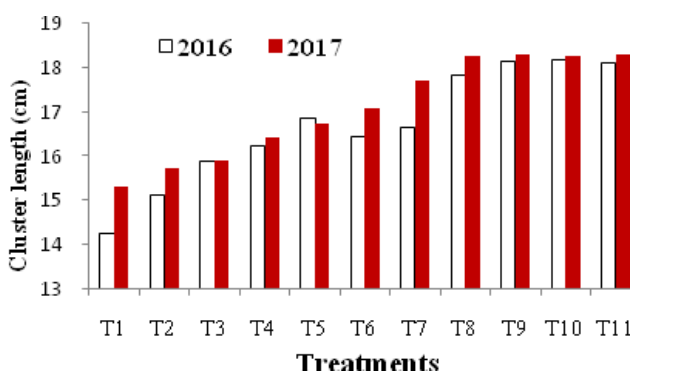

Total yield/ feddan (D)
Cluster length (B)

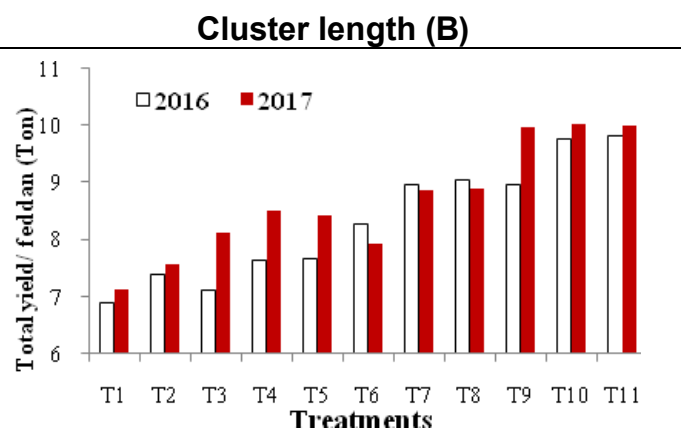

.

Cluster number (C)

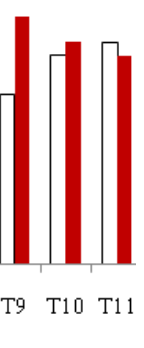

C)

Figures 2: Effect of Humic acid, Potassium silicate and biofertilizer on cluster weight (A), length (B), number (C) and yield/ feddan (D) of "Ruby Seedless" grapevines during 2016 and 2017 seasons

$T_{1}=$ Control, $T_{2}=$ Humic acid at $15 \mathrm{~g} / \mathrm{vine}, T_{3}=$ Humic acid at $30 \mathrm{~g} / \mathrm{vine}, T_{4}=$ Potassium silicate at $20 \mathrm{~g} / \mathrm{vine}$, $T_{5}=$ Potassium silicate at $40 \mathrm{~g} / \mathrm{vine}, T_{6}=$ Humic acid at $15 \mathrm{~g}+$ Biofertilizer at $50 \mathrm{~g} / \mathrm{vine}, T_{7}=$ Humic acid at $30 \mathrm{~g}+$ Biofertilizer at $50 \mathrm{~g} / \mathrm{vine}, T_{8}=$ Potassium silicate at $20 \mathrm{~g}+$ Biofertilizer at $50 \mathrm{~g} / \mathrm{vine}, T_{9}=$ Potassium silicate at $\mathbf{4 0 g}+$ Biofertilizer at $50 \mathrm{~g} / \mathrm{vine}, \mathrm{T}_{10}=$ Humic acid at $15 \mathrm{~g}+$ Potassium silicate at $\mathbf{2 0 g}+$ Biofertilizer at 50g/vine and $T_{11}=$ Humic acid at $30 \mathrm{~g}+$ Potassium silicate at $40 \mathrm{~g}+$ Biofertilizer at $50 \mathrm{~g} / \mathrm{vine}$.

These results were supported by correlation ( $r$ ) data presented in Table (4) which cleared that yield/ feddan showed a positive correlation vs. leaf area $\left(0.85^{*}\right)$, pruning's weight $\left(0.82^{*}\right)$ cluster weight $\left(0.92^{* *}\right)$ however, it negatively correlated vs. leaf proline content $\left(-0.88^{*}\right)$ and berry acidity $\left(-0.73^{*}\right)$. These results are in line with those of Calvo et al. (2014) they cleared the beneficial effects of humic acid as plant bio-stimulant which can improve yield and fruit quality characters of horticultural crops, and mitigate stresses. Also, biofertilizer applications produced best cluster physical properties of "Thompson Seedless" and "Flame Seedless" grapevines cultivars (EI-Sabagh et al., 2011). Moreover, potassium silicate supplement helps to mitigate the inhibited effects caused by salinity and increased the total yield of "Cabernet Sauvignon" grapevine (Qin et al., 2016). In addition, AlWasfy (2014) reported that the application of silicon compounds as a foliar spray or soil drench was effective in alleviating the adverse effect of environmental unsuitable conditions which resulted in improving cluster parameters and total yield of "Flame Seedless" grapes.

\section{Berry physical parameters}

As showed in Figures $\left(3_{A-C}\right)$ The combination between potassium silicate and biofertilizer ( $T_{8}$ and $\left.T_{9}\right)$ as well as the interaction between Humic acid and potassium silicate at both low and high levels plus biofertilizer ( $T_{10}$ and $\left.T_{11}\right)$ treatments produced the highest values 
of weight of 100 berries and berry diameter in both seasons. However, the highest volume of 100 berries was recorded by vines received $T_{10}$ and $T_{11}$ applications. On the other hand, vines of control $\left(T_{1}\right)$ showed the lowest values of all the above-mentioned parameters in both seasons. These results might be due to the effective role of biofertilizers on fixation atmospheric $\mathbf{N}$, simplify soil potassium, phosphorus and enhancing soil nutrients availability that accelerate carbohydrate synthesis that encourage cell division and development of meristemic tissues, that reflected on fruit quality and yield (Kannaiyan, 2002). Also, the addition of humic acid decreased soil pH that improved nutritional uptake consequently enhanced growth, berry size and total yield of "Italia" table grape (Ferrara et al., 2012). Si and Potassium applications offset partially the negative effects of salinity through increase the tolerance of grapevine, rising antioxidant enzymes activity and osmotic adjustment (Haddad and Kamangar, 2015).

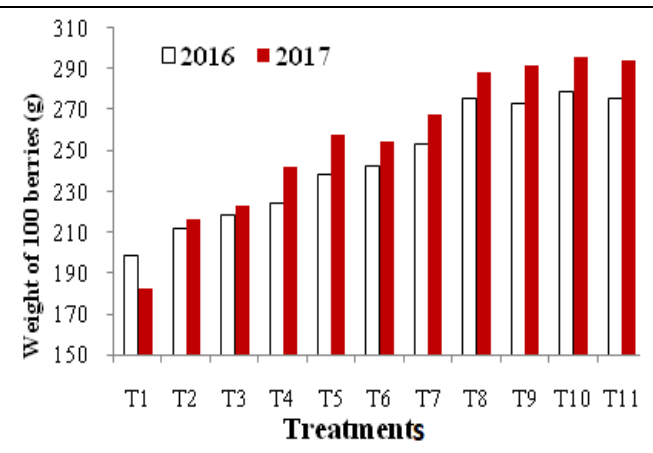

Weight of 100 berries (A)

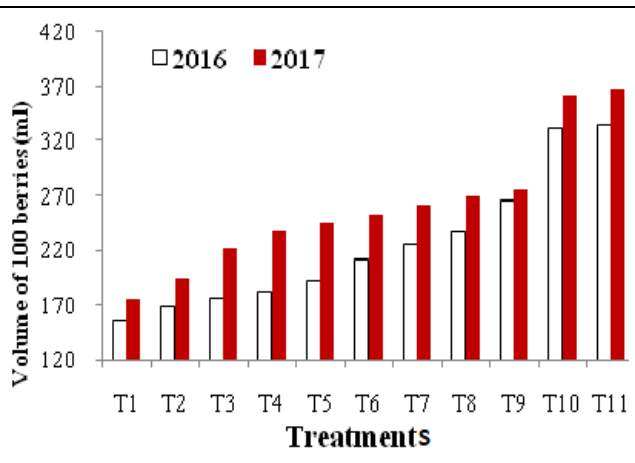

Volume of 100 berries(B)

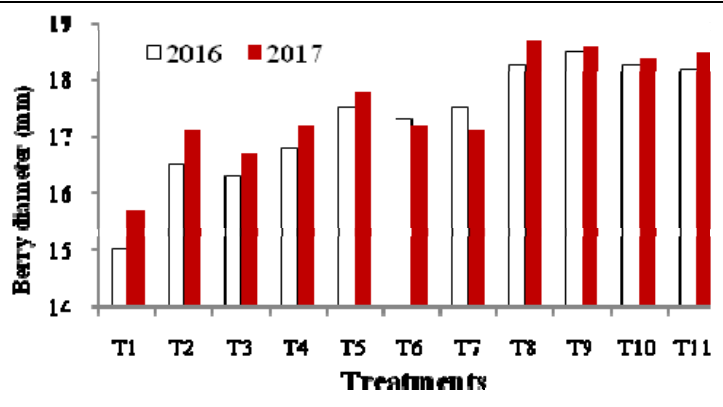

Berry diameter (C)

Figure3: Effect of Humic acid, Potassium silicate and biofertilizer on weight of 100 berries (A), volume of 100 berries (B) and berry diameter (C) of "Ruby Seedless" grapevines during 2016 and 2017 seasons

$T_{1}=$ Control, $T_{2}=$ Humic acid at $15 \mathrm{~g} / \mathrm{vine}, T_{3}=$ Humic acid at $30 \mathrm{~g} / \mathrm{vine}, T_{4}=$ Potassium silicate at $20 \mathrm{~g} / \mathrm{vine}$, $T_{5}=$ Potassium silicate at $40 \mathrm{~g} / \mathrm{vine}, T_{6}=$ Humic acid at $15 \mathrm{~g}+$ Biofertilizer at $50 \mathrm{~g} / \mathrm{vine}, T_{7}=$ Humic acid at $30 \mathrm{~g}+$ Biofertilizer at $50 \mathrm{~g} / \mathrm{vine}, T_{8}=$ Potassium silicate at $20 \mathrm{~g}+$ Biofertilizer at $50 \mathrm{~g} / \mathrm{vine}, T_{9}=$ Potassium silicate at $40 \mathrm{~g}+$ Biofertilizer at $50 \mathrm{~g} / \mathrm{vine}, T_{10}=$ Humic acid at $15 \mathrm{~g}+$ Potassium silicate at $20 \mathrm{~g}+$ Biofertilizer at $50 \mathrm{~g} / \mathrm{vine}$ and $\mathrm{T}_{11}=$ Humic acid at $30 \mathrm{~g}+$ Potassium silicate at $40 \mathrm{~g}+$ Biofertilizer at $50 \mathrm{~g} / \mathrm{vine}$. 


\section{Berry chemical parameters}

Data of Table (7) showed that the interaction between potassium silicate and biofertilizer $\left(T_{9}\right)$ as well as Humic acid (potassium humate) and potassium silicate at both lower and higher levels plus biofertilizer ( $\mathrm{T}_{10}$ and $\left.\mathrm{T}_{11}\right)$ treatments, gave the highest values of SSC \% and berries anthocyanin content. In the contrary, control vines and that received $\mathrm{T}_{2}$ showed the lowest values of both parameters in the two seasons. However, the application of $\mathrm{T}_{11}$ treatment, showed the lowest juice acidity\% and the highest values of $\mathrm{SSC} /$ acid ratio as compared to the others. On the other hand, control vines $\left(T_{1}\right)$ and that treated with $T_{2}$ application, showed the lowest values of
SSC\%, SSC/ acid ratio and anthocyanin contents. These results were supported by data presented in Table (4) where $\mathrm{SSCl}$ acid ratio cleared a positive correlation vs. leaf area $\left(0.80^{*}\right)$, pruning's weight $\left(0.89^{*}\right)$ cluster weight $\left(0.81^{*}\right)$, yield/ feddan $\left(0.77^{*}\right)$ and negatively correlated vs. leaf proline content $\left(-0.72^{*}\right)$ and berry acidity $\left(-0.99^{* *}\right)$. These results are in harmony with those of Mohamadineia et al. (2015) they reported that the addition of humic acid at $2.5,5$ and $7.5 \mathrm{~g} / \mathrm{L}$ improved SSC\%, SSC/ acidity ratio and juice $\mathrm{pH}$ of "Askari" grapevine. Moreover, the exogenous application of Silicon improved the salt tolerance of "Cabernet Sauvignon" grapevines by increasing soluble sugars (Qin et al., 2016).

Table 7: Effect of Humic acid, potassium silicate and biofertilizer on some chemical parameters of berries of "Ruby Seedless" grapevines during 2016 and 2017 seasons

\begin{tabular}{|c|c|c|c|c|c|c|c|c|}
\hline \multirow[t]{2}{*}{ Treatments } & \multicolumn{2}{|c|}{$\begin{array}{c}\text { SSC } \\
\%\end{array}$} & \multicolumn{2}{|c|}{$\begin{array}{c}\text { Acidity } \\
\%\end{array}$} & \multicolumn{2}{|c|}{$\begin{array}{l}\text { SSC/acid } \\
\text { ratio }\end{array}$} & \multicolumn{2}{|c|}{$\begin{array}{l}\text { Anthocyanine } \\
\text { (mg/100g FW) }\end{array}$} \\
\hline & 2016 & 2017 & 2016 & 2017 & 2016 & 2017 & 2016 & 2017 \\
\hline $\mathrm{T}_{1}$ & $16.40^{f}$ & $16.27^{d}$ & $0.69^{a}$ & $0.71^{a}$ & $23.77^{e}$ & $22.91^{9}$ & $24.52^{c}$ & $21.11^{c}$ \\
\hline$T_{2}$ & $16.47^{f}$ & $16.53^{d}$ & $0.68^{a}$ & $0.67^{a}$ & $24.22^{\mathrm{e}}$ & $24.68^{f}$ & $24.71^{\mathrm{c}}$ & $22.25^{c}$ \\
\hline$T_{3}$ & $16.87^{e}$ & $16.53^{d}$ & $0.67^{a}$ & $0.65^{\mathrm{abc}}$ & $25.17^{\text {de }}$ & $25.44^{\text {ef }}$ & $25.21^{b c}$ & $26.37^{b}$ \\
\hline $\mathrm{T}_{4}$ & $17.20^{d}$ & $17.33^{c}$ & $0.66^{\mathrm{a}}$ & $0.65^{\mathrm{abc}}$ & $26.06^{c d}$ & $26.67^{\mathrm{de}}$ & $25.64^{\mathrm{bc}}$ & $26.65^{b}$ \\
\hline$T_{5}$ & $17.73^{b c}$ & $17.53^{c}$ & $0.68^{a}$ & $0.66^{\mathrm{ab}}$ & $26.08^{c d}$ & $26.57^{\mathrm{de}}$ & $25.93^{b c}$ & $26.47^{b}$ \\
\hline$T_{6}$ & $17.47^{c}$ & $17.53^{c}$ & $0.67^{a}$ & $0.64^{\mathrm{abc}}$ & $26.07^{c d}$ & $27.40^{\mathrm{cd}}$ & $26.34^{b c}$ & $26.67^{b}$ \\
\hline$T_{7}$ & $17.73^{b c}$ & $17.67^{c}$ & $0.65^{a b}$ & $0.63^{a b c}$ & $27.28^{c}$ & $28.04^{\text {cd }}$ & $26.75^{a b c}$ & $26.95^{\mathrm{ab}}$ \\
\hline$T_{8}$ & $17.93^{b}$ & $18.13^{b}$ & $0.62^{\mathrm{ab}}$ & $0.63^{a b c}$ & $28.92^{b}$ & $28.78^{c}$ & $27.32^{\mathrm{ab}}$ & $27.04^{\mathrm{ab}}$ \\
\hline$T_{9}$ & $18.27^{a}$ & $18.47^{a}$ & $0.63^{\mathrm{ab}}$ & $0.57^{\mathrm{bcd}}$ & $28.99^{b}$ & $32.40^{b}$ & $28.74^{a}$ & $28.68^{a}$ \\
\hline$T_{10}$ & $18.33^{a}$ & $18.53^{a}$ & $0.61^{a b}$ & $0.56^{\mathrm{cd}}$ & $30.05^{b}$ & $33.10^{b}$ & $28.79^{a}$ & $28.71^{a}$ \\
\hline $\mathbf{T}_{11}$ & $18.53^{a}$ & $18.67^{a}$ & $0.57^{\mathrm{b}}$ & $0.52^{d}$ & $32.51^{a}$ & $35.90^{\mathrm{a}}$ & $29.12^{\mathrm{a}}$ & $28.70^{a}$ \\
\hline
\end{tabular}

In a column, numbers followed by the same litter had no significant difference at $5 \%$ level by DMRT.

$T_{1}=$ Control, $T_{2}=$ Humic acid at $15 \mathrm{~g} / \mathrm{vine}, T_{3}=$ Humic acid at $30 \mathrm{~g} / \mathrm{vine}, T_{4}=$ Potassium silicate at $20 \mathrm{~g} / \mathrm{vine}$, $T_{5}=$ Potassium silicate at $40 \mathrm{~g} / \mathrm{vine}, T_{6}=$ Humic acid at $15 \mathrm{~g}+$ Biofertilizer at $50 \mathrm{~g} / \mathrm{vine}, T_{7}=$ Humic acid at $30 \mathrm{~g}+$ Biofertilizer at $50 \mathrm{~g} / \mathrm{vine}, T_{8}=$ Potassium silicate at $20 \mathrm{~g}+$ Biofertilizer at $50 \mathrm{~g} / \mathrm{vine}, T_{9}=P$ Potassium silicate at $40 \mathrm{~g}+$ Biofertilizer at $50 \mathrm{~g} / \mathrm{vine}, \mathrm{T}_{10}=$ Humic acid at $15 \mathrm{~g}+$ Potassium silicate at $20 \mathrm{~g}+$ Biofertilizer at $50 \mathrm{~g} / \mathrm{vine}$ and $T_{11}=$ Humic acid at $30 \mathrm{~g}+$ Potassium silicate at $40 \mathrm{~g}+$ Biofertilizer at $50 \mathrm{~g} / \mathrm{vine}$. 


\section{Soil EC, pH and available nutrients}

Data illustrated as Figures (4A-E) declared that, the applications of humic acid, Potassium silicate and biofertilizer were effective in decreasing soil electric conductivity (EC) and soil $\mathrm{pH}$ after the experiment as compared with those values before conducting the experiment. The application of $T_{10}$ and $T_{11}$ treatments gave the lowest values of soil EC and $\mathrm{pH}$ as compared with the others. Moreover, the same treatments $\left(T_{10}\right.$ and $\left.T_{11}\right)$ showed the highest values of soil $N, P$ and $K$ contents at the end of the study followed by $T_{9}$ and $T_{8}$, respectively. The effect of treatments on soil EC, $\mathrm{pH}$ and available nutrients might do to the role of humus complex which conceders as an effective amelioration method to remove exchange soluble sodium and changing the ionic composition of the soil, also leaching the sodium salts out of the soil profile (Ouni et al., 2014). Moreover, Humic acid and biofertilizer applications improved soil properties as aggregation, hydraulic conductivity, bulk density, EC and $\mathrm{pH}$ and caused an increase in N, P, K, Fe, Mn and $\mathrm{Zn}$ of Clementine orchard soil under saline water irrigation (Abed El-Hamied, 2014).

\section{Soil microbial activity}

The results of soil microbial activity showed in Figure (4F) indicated that the using of Humic acid or Potassium silicate alone and in combined with biofertilizer were very effective for enhancing soil microorganism's activity measured as $\mathrm{CO}_{2}$ ( $\mathrm{mg} / \mathrm{kg}$ of soil) produced as an indicator. All treatments enhanced this activity, especially the addition of $T_{8}, T_{9}$, $T_{10}$ and $T_{11}$ in ascending degree. These results are in line with those of Khattak et al., (2013) and Mohamed et al., (2013) they summarized that the addition of biofertilizers (mixture of Cyanobacteria and Azolla) enhanced biological activity in root rhizosphere under salt-affected soil, in terms of total bacterial counts, total cyanobacterial counts, and $\mathrm{CO}_{2}$ evolution as compared to control. 


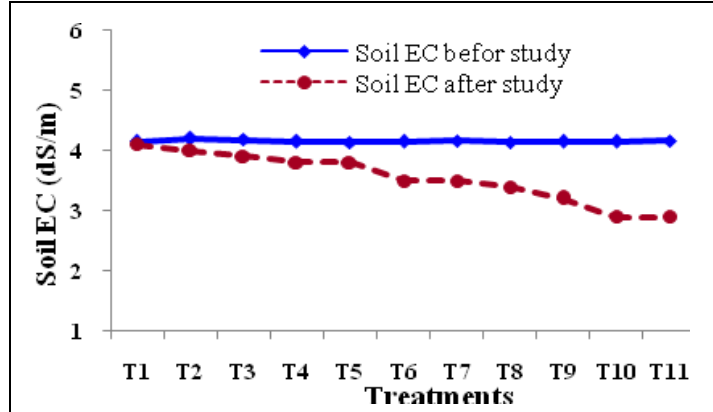

(A)

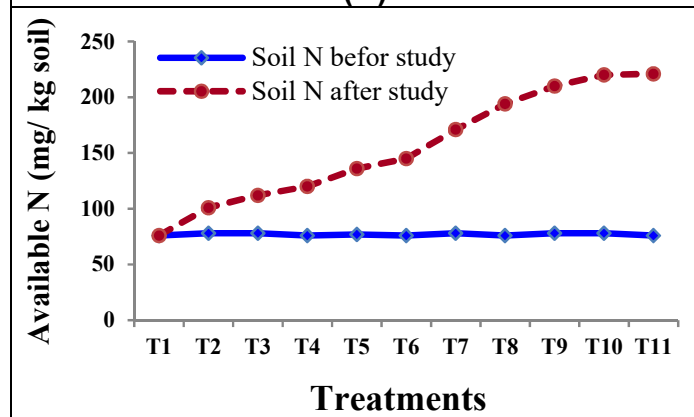

(C)

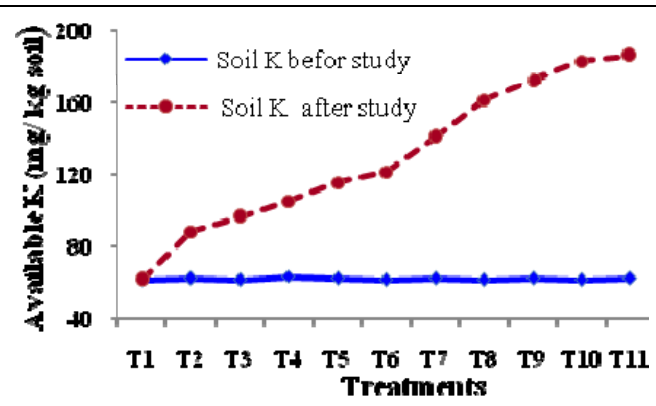

(E)

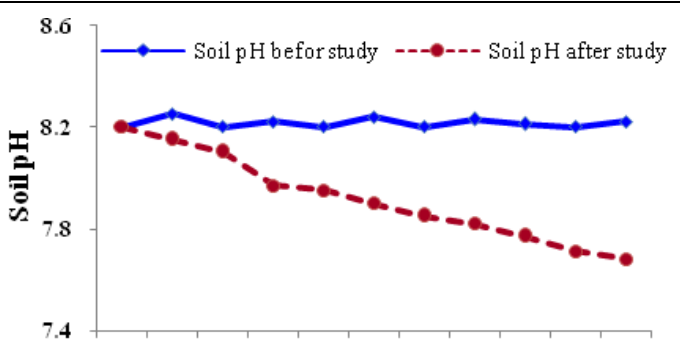

$\begin{array}{lllllllllll}\text { T1 } & \text { T2 } & \text { T3 } & \text { T4 } & \text { T5 } & \text { T6 } & \text { T7 } & \text { T8 } & \text { T9 } & \text { T10 } & \text { T11 }\end{array}$ Treatments

(B)

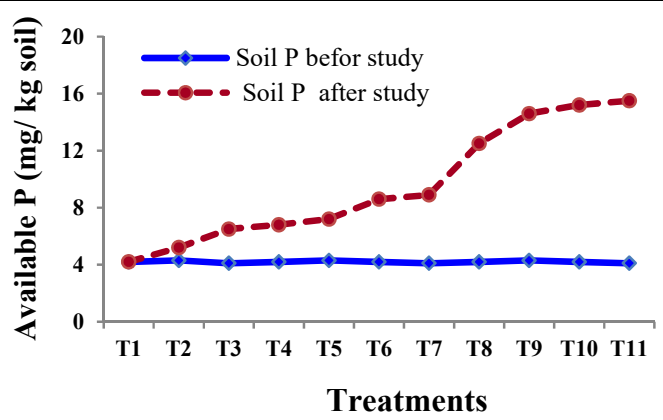

(D)

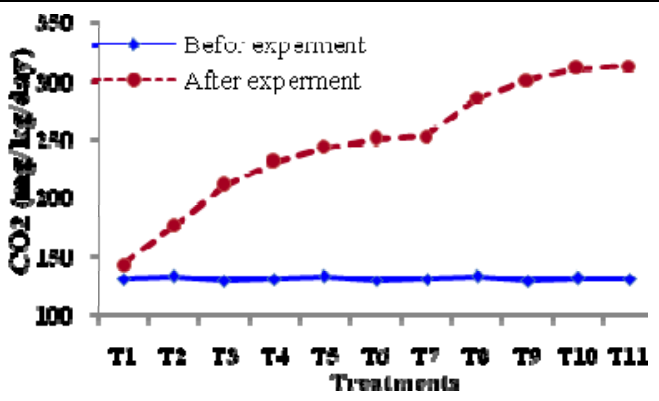

(F)

Figure 4. Effect of Humic acid, Potassium silicate and biofertilizer on soil EC (A), pH (B), nitrogen (C), phosphor (D), potassium (E) and microbial activity as $\mathrm{Co}_{2}(\mathrm{mg} / \mathrm{kg}$ soil/ day) (E) before beginning treatments and at the end of experiment

$T_{1}=$ Control, $T_{2}=$ Humic acid at $15 \mathrm{~g} /$ vine, $T_{3}=$ Humic acid at $30 \mathrm{~g} / \mathrm{vine}, T_{4}=$ Potassium silicate at $20 \mathrm{~g} / \mathrm{vine}$, $T_{5}=$ Potassium silicate at $40 \mathrm{~g} / \mathrm{vine}, T_{6}=$ Humic acid at $15 \mathrm{~g}+$ Biofertilizer at $50 \mathrm{~g} / \mathrm{vine}, T_{7}=$ Humic acid at $30 \mathrm{~g}+$ Biofertilizer at $50 \mathrm{~g} / \mathrm{vine}, T_{8}=$ Potassium silicate at $20 \mathrm{~g}+$ Biofertilizer at $50 \mathrm{~g} / \mathrm{vine}, T_{9}=$ Potassium silicate at $40 \mathrm{~g}+$ Biofertilizer at $50 \mathrm{~g} / \mathrm{vine}, \mathrm{T}_{10}=$ Humic acid at $15 \mathrm{~g}+$ Potassium silicate at $20 \mathrm{~g}+$ Biofertilizer at 50g/vine and $T_{11}=$ Humic acid at $30 \mathrm{~g}+$ Potassium silicate at $40 \mathrm{~g}+$ Biofertilizer at $50 \mathrm{~g} / \mathrm{vine}$.

\section{CONCLUSION}

According the results of this study, application of Humic acid, potassium silicate and biofertilizer containing (Azotobacter chroococcum+ Azospirllium lipoferm+ Bacillus megatherium with a density $1 * 10^{8} \mathrm{CFU} / \mathrm{g}$ ) were effective to mitigating the salinity stress on "Ruby
Seedless" grapevines grown in salt affected soil. Humic acid at $30 \mathrm{~g}+$ potassium silicate at $\mathbf{4 0} \mathrm{g}+$ biofertilizer at $50 \mathrm{~g} /$ vine treatment gave the best vegetative growth, vine vigor, yield and fruit quality and reduced soil $\mathrm{EC}, \mathrm{pH}$, and enhanced soil available NPK as well as microorganisms activity. 


\section{REFERENCES}

A.O.A.C., (1995). Official Methods of Analysis 16th Edition. Association of official Analytical Chemists Washington D.C., USA.

Abd El-Hamied, S. A. (2014). Effect of multi ingredient of Bokashi on productivity of mandarin trees and soil properties under saline water irrigation, Journal of Agriculture and Veterinary Science, 7(11, II):79- 87.

Ahmed, F.F. and M.H. Morsy (1999). A new method for measuring leaf area in different fruit species. Minia J. Agric. Res. Develop., 19(1):96-105.

Ali, M. A.; S. S. El-Gendy and O. A. Ahmed (2013). Minimizing adverse effects of salinity in vineyards. $J$. Hort.Sci. \& Ornamen. Plants, 5(1): 12 21.

Al-Wasfy, M. M. (2014). The synergistic effects of using silicon with some vitamins on growth and fruiting of Flame Seedless grapevines. Stem Cell, 5(1): 8-12.

Anandaraj, B. and L.R.A.Delapierre (2010) Studies on influence of bioinoculants (Pseudomonas fluorescens, Rhizobium sp., Bacillus Megaterium) in green gram. J. Biosci Tech., 1(2): 95-99.

Ayers, R.S. and D.W. Westcot (1985) Water quality for agriculture, FAO Irrigation and Drainage Paper No. 29, (Rev.), FAO, Rome, pp: 174

Aziz, M. T.; M. A. Gill, and R. Rahmatullah (2002). Silicon nutrition and crop production. Review in J. of Agric. Sci. 39(3): 181-187.

Bates, L. S., R. P. Waldren and I.D. Teare (1973). Rapid determination of free proline for water stress studies. Plant and Soil, 39: 205-207.

Bockhaven, V. J.; D. Vleesschauwer and M. Höfte (2013). Towards establishing broad-spectrum disease resistance in plants: silicon leads the way. J. Exp. Bot. 64(5):128-129.
Bouard, J. (1966). Recherches physiologiques sur la vigne et en particulier pour L'aoutment des sarments. Sc. Thesis, Nat Bordeaux, France.

Buyukkeskin, T. and S. Akinci (2011). The Effects of Potassium humate on Above-ground Parts of Broad Bean (Vicia faba L.) Seedlings Under Al (3+) toxicity. Fresen. Environ. Bull. 20(3): 539-548.

Calvo, P., L. Nelson and J. W. Kloepper (2014). Agricultural uses of plant biostimulants. Plant and Soil, 383, 3 41. http://dx.doi. Org/ 10. $1007 /$ s11104 -014- 2131- 8.

Cavalcante, I. H. L., R.R.S. Da-Silva, F.G. Albano, G. B. Da-Silva, A. M. Silva and L. S. Costa (2013). Foliar spray of humic substances on seedling production of yellow passion fruit. Journal of Food, Agriculture \& Environment 11(2):301 - 304.

Celik, H., K.A. Vahap, A. B. Bulent and M. A. Turan (2011). Effect of Foliarapplied Potassium humate to Dry Weight and Mineral Nutrient Uptake of Maize Under Calcareous Soil Conditions. Comm. Soil Sci. Plant Anal. 42(1): 29-38.

Cramer, G.R., A. Ergul, J. Grimple, R.L. Tillett, C. Osborne, D. Quilici, K.A. Schlauch, D.A. Schooley and J.C. Cushman (2007). Water and salinity stress in grapevines: early and late changes in transcript and metabolite profiles. Funct. Integr. Genomics, 7:111-134.

Davies, W. and J. Zhang (1991). Root signals and the regulation of growth and the development of plants in drying soil. Annual Review of Plant Physiology and Plant Molecular Biology 42: 55-76.

Davis, G. and E.A. Ghabbour (1998). Humic substances, structure properties and uses. Royal Soc. Of Chemistry, Cambridge, pp. 10 -15. 
Duncan, B. D. (1955). Multiple test range and multiple $F$ tests. Biometrics., pp: 1I-42.

El-Rawy, H. A. (2007). Physiological studies on fertilization of King Ruby grapevines Ph.D. Thesis, Fac. Agric, Assiut Univ., pp: 162.

El-Sabagh, A.S., F.M. El-Morsy and A.R. Farag (2011). Effect of Biofertilizers as a Partial Substitute for Nitrogen Fertilzier on Vegetative Growth, Yield, Fruit Quality and Leaf Mineral Content of Two Seedless Grape Cultivars II: Fruit Quality and Leaf Mineral Content. Journal of Horticultural Science \& Ornamental Plants, 3 (2): 176-187.

Epstein, E. and A. J. Bloom (2005). Mineral Nutrition on Plants: Principles and Perspectives. $2^{\text {nd }}$ ed. Sinauer Associates, Sunderland, MA,USA.

Ferrara, G. and G. Brunetti (2010). Effects of the times of application of a soil potassium humate on berry quality of table grape (Vitis vinifera L.) Cv. Italia. Spanish J. Agric., Res. 8(3): 817 - 822.

Ferrara, G., A. Pacifico, P. Simeone and E. Ferrara (2012). Preliminary study on the effects of foliar applications of potassium humates on 'italia' table grape

Gabr, M.A. and M. Nour El-Din (2012). Evaluation of selected Azospirillum spp. isolates for IAA production and fruit potential impact on improving growth, yield and fruit quality of Anna apple trees. J. Agric. Chem. and Biotechn., Mansoura Univ., 3(3): 65 75.

Gaur, A.C., K.V. Sadasivam, O.P. Vimal and R.S. Mathur (1971). A study on the decomposition of organic matter in an alluvial soil: $\mathrm{CO} 2$ evolution, microbiological and chemical transformations. Plant and Soil, 35(1): $17-28$.

Haddad, R. and A. Kamangar (2015). The ameliorative effect of silicon and potassium on drought stressed grape (Vitis vinifera L.) leaves. Iranian J. of
Genetics and Plant Breeding, 4 (2): 4858

Haynes, R. J. (2014). A contemporary over view of silicon availability in agricultural soils. J. PlantNutr. SoilSci. 177: 831-844.

Hodge, J.E. and B.T. Hofreiter (1962) Analysis and Preparation of Sugars. In: Whistler, R.L. and Miller, J.N.B., Eds., Methods in Carbohydrate Chemistry, 6th Edition, Academic Press, New York, 356-378.

Hsia, C.L., B.S. Luh and C.O. Chichester (1965). Anthocyanin in freestone peaches. J. Food Sci., 30: 5-12.

Jackson, M.L. (1973). Soil Chemical

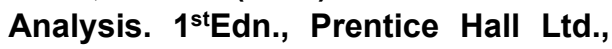
New Delhi, India, Pages: 498.

Kannaiyan, S. (2002). Biotechnology of biofertilziers. Alpha Sci. Inter. Ltd., P.O. Box 4067 Pangbourne AG \& But, M.K.P. 1-375.

Khalil, H. A. (2012). The Potential of Biofertilizers to Improve Vegetative Growth, Nutritional Status, Yield and Fruit Quality of Flame Seedless Grapevines. American-Eurasian J. Agric. \& Environ. Sci., 12 (9): 11221127.

Khattak, R.A., K. Haroon and D. Muhammad (2013). Mechanism(s) of humic acid induced beneficial effects in salt-affected soils. Scientific Research and Essays 8(21):932- 939.

Liang, Y., W. Sun, Y.G. Zhu and P. Christie (2007). Mechanisms of silicon mediated alleviation of abiotic stresses in higher plants: a review. Environ Pollut., 147: 422-428.

Mansour, A.E.M., F.F. Ahmed, A.M.K. Abdelaal, R.A.R. Eissa and O.A.M. Sehrawy (2013). The beneficial of using some biostimulants as a partial replacement of chemical $\mathbf{N}$ fertilizers in Florida prince peach orchards. $J$. Appl. Sci. Res., 9(1): 867 - 871.

Mazumdar, B.C. and K. Majumder (2003). Methods on physic -chemical analysis 
of fruits. College of Agriculture. Calcutta Univ., pp: 108 - 109.

Meunier, M., S. Rogiers, G. Gurr and R. Siret (2011). Grapevine vegetative growth and reproductive development in response to silicon supplemen. Proceedings of the $5^{\text {th }}$ International Conference on Silicon in Agriculture September 13-18, Beijing, China, pp126.

Mohamadineia, G., M.H. Farahi and M. Dastyaran (2015). Foliar and Soil Drench Application of Humic acid on Yield and Berry Properties of "Askari" Grapevine. Agricultural Communications, 3 (2): 21-27.

Mohamed, H.M., F.A. Al-Kamar and A.A. Abd-Elall (2013). Effect of magnetite and some biofertilizer application on growth and yield of Valencia orange trees under El-Bustan condition. Nature and Science, 11(6):46 - 61.

Murkute,A. A., S. Sharma and S. K. Singh(2005). Citrus in terms of soil and water salinity: A review. Journal of Scientific \& Industrial Research, 64, 393-402.

Obbink, J.G. and D.M. Alexander (1973). Response of six grapevine cultivars to a range of chloride concentrations. Am. J. Enol. Viticulture, 24: 65-68.

Ouni, Y., T. Ghnaya, F. Montemurro, C. Abdelly and A. Lakhdar (2014). The role of humic substances in mitigating the harmful effects of soil salinity and improve plant productivity. International Journal of Plant Production 8(3): $353-374$.

Page, A.L., H. Miller and D.R. Keeney (1982). Methods of soil analysis. Part 2: Chemical and microbiological properties. 2nd Edition, Agronomy Monograph, No. 9, ASA, CSSA, and SSSA, Madison.

Pregl, F. (1945). Quantitative organic microanalysis, 4thed J.A. Churchill, Ltd, London.

Qin, L., W. Kang, Y. Qi, Z. Zhang and N. Wang (2016). The influence of silicon application on growth and photosynthesis response of salt stressed grapevines (Vitis vinifera L.). Acta Physiol. Plant, 38:68-77.

Salisbury, F.B. and C.W. Ross (1992). Plant physiology. Pub. Wadsworth, Belmont, California, USA.

Snedecor, G. W. and W. G. Cochran (1980). Statistical methods. 6th Ed. lowa State Univ. Press. Ames.

Snell, F. D. and C. T. Snell (1967). Colorimetric Method of Analysis. D. van Nestrant Company Inc., pp: 551552.

Soliman, M. A. M., H. M. Abo-Ogiela and N. A. El-Saedony (2013). Reducing Adverse Effects of Salinity in Peach Trees Grown in Saline Clay Soil. Journal of Horticultural Science \& Ornamental Plants, 5 (1):12-21

Tahir, M. M., M. Khurshid, M. Z. Khan, M. K. Abbasi and M. H. Kazmi (2011). Lignite-derived Potassium humate Effect on Growth of Wheat Plants in Different Soils. Pedosphere. 21(1): 124-131.

Tenshia, J.S.V. and P. Singaram (2005). Influence of humic acid application on availability and uptake in tomato. The Madrass Agric. J., 92:670- 676.

Tuna, A.L., C. Kaya, D. Higgs, B. MurilloAmador, S. Aydemir and A.R. Girgin (2008). Silicon improves salinity tolerance in wheat plants. Environ Exp, Bot, 62:10-16.

Walker, R. R., P.E. Read, R.R. Walker and D.H. Blackmore (2008). Rootstock and salinity effects on rates of berry maturation, ion accumulation and colour development in Shiraz grapes. Aust J Grape Wine Res 6: 227-239

West, D. W. (1986). Stress physiology in trees-salinity. ActaHorticulturae. 175: 321- 332.

Wettstein, D. (1957). Chlorophyll- letale und der Submikro Skopische Formwechsel de plastiden, Experimental cell research 12, 427437. 
تخفيف الاثار السلبية لملوحة التربة على نمو و انتاجية كروم العنب روبى سيدلس باستخدام بعض محسنات التربة

\author{
منال جمال محمد ابراهيم ، صابر سعد بسيونى

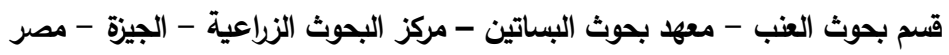

الملخص العربى

تعد الملوحة احد اهم العوامل التى تواجه التوسع الزراعى لتاثيراتها السلبيةعلى النمو والانتاج. وعلية فقد أجريت هذه

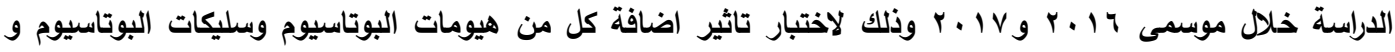

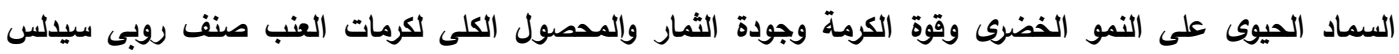

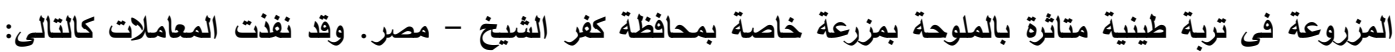

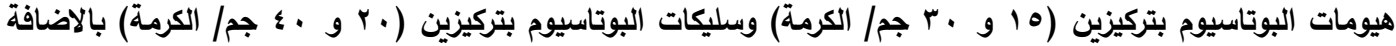

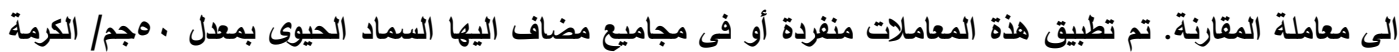

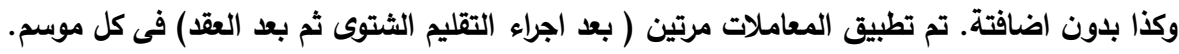
أوضحت النتائج ان هذه المعاملات كانت ذات تأثير ايجايى فى الحد من تأثيرات الملوحة على الكرمات فى مقابل معاملة المقارنة. وكانت المعاملات فى مجاميع تثمل كل من هيومات البوتاسيوم وسليكات البوتاسيوم بكلا التركيزين

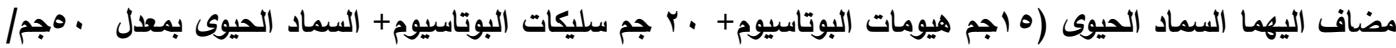

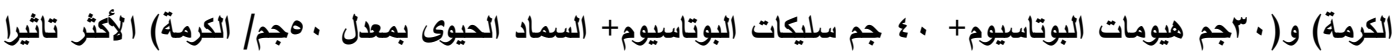

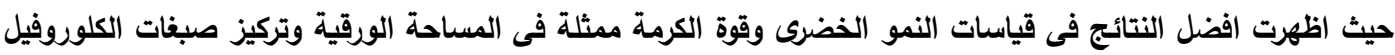
وعدد الاورلق على الفرع ومعامل نضج الخشب ووزن خشب التقليم وطول وقطر السلميات. كما انها اظهرت زيادة معنوية فى محتوى الاولق من عناصر النيتروجين واللفوسفور والبوتاسيوم واظهرت انخفاض فى محتوى الاورلق من البرولين.

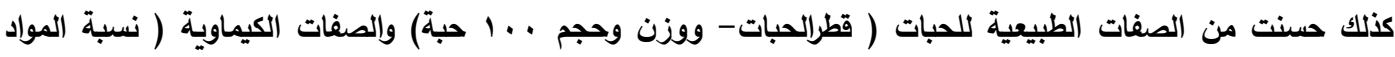
الصلبة الذائبة- نسبة المواد الصلبة الذائبة/ الحموضة- محتوى الثمار من صبغات الانثوسيانين) وكذا علد العات العناقيد وطول ووزن العنقود مما ادى الى زيادة المحصول الكلى للفدان فى مقابل معاملة المقارنة. كذلك فانها كانت الاكثر تأثيرا

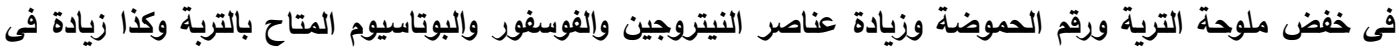
نشاط المحتوى الميكروبى للترية.

أسماء السادة المحكمين

أ.د/ علاء الدين خليل سعد عمر كلية الزراعة-جامعة كفر الثيخ الثين

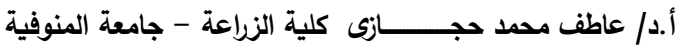

